\title{
EVALUATION OF ICHNODIVERSITY BY IMAGE-RESAMPLING METHOD TO CORRECT OUTCROP EXPOSURE BIAS
}

\section{$\operatorname{AUTHOR}(S)$ :}

KIKUCHI, KAZUKI; NARUSE, HAJIME; KOTAKE, NOBUHIRO

\section{CITATION:}

KIKUCHI, KAZUKI ...[et al]. EVALUATION OF ICHNODIVERSITY BY IMAGERESAMPLING METHOD TO CORRECT OUTCROP EXPOSURE BIAS.

PALAIOS 2018, 33(5): 204-217

\section{ISSUE DATE:}

2018-05-01

URL:

http://hdl.handle.net/2433/231110

\section{RIGHT:}

This is the accepted manuscript of the article, which has been published in final form at

https://doi.org/10.2110/palo.2017.090; The full-text file will be made open to the public on 01 May 2019 in accordance with publisher's 'Terms and Conditions for Self-Archiving'; This is not the published version. Please cite only the published version.; この論文は出版社版でありません。引用の際には出版社版をご確認ご利用ください。 
1 EVALUATION OF ICHNODIVERSITY BY IMAGE-RESAMPLING METHOD TO CORRECT OUTCROP EXPOSURE BIAS

KAZUKI KIKUCHI ${ }^{1}$, HAJIME NARUSE ${ }^{1}$, and NOBUHIRO KOTAKE ${ }^{2}$

$4{ }^{1}$ Department of Geology and Mineralogy, Graduate School of Science, Kyoto University,

62 Department of Earth Sciences, Graduate School of Science, Chiba University, 1-33,

$8 \quad$ email:kikuchi@kueps.kyoto-u.ac.jp

9 RRH: NEW EVALUATION METHOD OF ICHNODIVERSITY

10 LRH: K. KIKUCHI ET AL. 


\section{ABSTRACT}

We propose a new method to evaluate the diversity of ichnofossils from

13 outcrop. Ichnodiversity (defined here as the number of ichnotaxa) characterizes

14 paleoenvironmental conditions. However, the apparent numbers of ichnotaxa

15 observed in outcrops are significantly affected by differences in areas of exposed

16 outcrops. This study proposes a new method to evaluate ichnodiversity, independent of

17 outcrop exposure bias, by using an image-resampling technique combined with the

18 shareholder quorum subsampling method. In this method, the relationship between

19 observed and detected numbers of ichnotaxa is estimated by subsampling from

20 existing outcrop images. The relative diversity of ichnotaxa is obtained at a given

21 value of the estimated coverage parameter, representing the ratio of the observed

22 number of ichnotaxa to the actual diversity. The method was verified by analyzing

23 artificial images of ichnoassemblages, and the method successfully estimated

24 reasonable values of relative diversity of ichnotaxa. It was also suggested that the

25 spatial distribution patterns of ichnofossils on the bedding planes does not affect the

26 estimated intensity of ichnodiversity when using this method. This method was also

27 applied to field data pertaining to deposits of the submarine channel-levee complex in

28 the Oligocene Izaki Olistolith of the Nichinan Group, southwest Japan. As a result, the

29 ichnodiversity of the successions in the Izaki Olistolith was reconstructed to be

30 relatively high in channel deposits and low in levee deposits. 
Ichnofossils represent a record of the response of ancient benthic animals to

34 changes in environmental conditions. Therefore, ichnological data are important for

35 assessing sedimentary environments of the sea floor and also to understand the ethology of

36 ancient benthic animals.

37 Ichnodiversity, which is regarded as the number of ichnotaxa at the ichnogenus

38 level, is an important and useful parameter for evaluating sedimentary environments of the

39 seafloor. Many studies have assessed not only the physicochemical disturbances including

40 sedimentation rate, energy level, sediment properties, salinity, and pore water oxygenation

41 (Bromley and Ekdale 1984; Buatois et al. 1997; Knaust 2007; Heard and Pickering 2008;

42 Hauck et al. 2009; Cummings and Hodgson 2011; Gingras et al. 2011; Phillips et al. 2011;

43 Callow et al. 2013; Heard et al. 2014; Bayet-Goll et al. 2015; Timmer et al. 2016), but also

44 biological factors such as organic matter input (Pearson and Rosenberg 1978; Wetzel and

45 Uchman 1998; Hyland et al. 2005; Callow et al. 2014). In addition, ichnodiversity is

46 strongly controlled by differences in sedimentary facies: the diversity of ichnotaxa found in

47 the submarine channel facies seems to be lower than that in the levee facies (Heard and

48 Pickering 2008; Cummings and Hodgson 2011; Phillips et al. 2011; Callow et al. 2013;

49 Heard et al. 2014). Furthermore, ichnodiversity can also provide informative data for the

50 evolutionary history of ethological strategies of benthic communities (Uchman 2003;

51 Buatois et al. 2016).

52 Previous studies have discussed ichnodiversity based on qualitative data using the

53 apparent number of ichnotaxa at the ichnogenus level obtained from outcrop observations

54 (Buatois and Mángano 2013). The apparent numbers of ichnotaxa strongly reflect not only 
55 the actual diversity in activities of benthic animals, but also exposed areas of observed

56 outcrops (Orr 2001). In the case of outcrop observation, the numbers of ichnotaxa must be

57 simply increased by increasing the area of the observed bedding plane. The observational

58 biases mentioned above can be treated as types of sample size effects. Thus, quantitative

59 approaches are required for evaluation of ichnodiversity (Buatois et al. 2016).

Several established methods are available for correcting sample size effects in

61 studies of ecology and paleobiology. For instance, the rarefaction method (Sanders 1968) is

62 a traditional method to compare biodiversity among assemblages with respective sample

63 sizes. In this method, rarefaction curves for each assemblage, which show relationships

64 between sample size and expected species richness, are described to standardize diversity at

65 a given sample size (e.g., Hurlbert 1971). This method is suitable when size of collected

66 samples is significantly large and the diversity of communities is relatively low (Alroy

67 2010c; Chao and Jost 2012). However, this method tends to underestimate biodiversity,

68 especially in highly diverse communities because estimated biodiversity standardized by

69 sample size strongly depends on species-abundance distributions of the real communities

70 (Alroy 2010c; Chao and Jost 2012). The estimated biodiversity of a community with a

71 small number of taxa can be saturated at relatively small sample sizes, but this is not

72 adequate for a highly diverse community. Therefore, comparison of biodiversity based on

73 the sample size is not usually "fair" because the sample diversity of one community might

74 cover nearly all of the real diversity, whereas the sample diversity of the other community

75 might represent only a part of the real diversity (Chao and Jost 2012). Recently, Alroy

76 (2010b, 2010c) proposed the shareholder quorum subsampling (SQS) method to solve this 
77 problem. In this method, the biodiversity of communities are compared with each other at

78 the same value of the sample coverage parameter, which represents the sum of frequencies

79 of each taxon included in hypothetical populations (Alroy 2010a, 2010b, 2010c; Chao and

80 Jost 2012). The sample coverage is estimated by Good-Turing frequency estimation (Good

81 1953) or the slope of the tangential lines of the rarefaction curves (Chao and Jost 2012).

82 Even though the species richness value estimated by the SQS method is always lower than

83 the real diversity, the ratio of species richness values between any two samples is expected

84 to match the ratio of the real diversity of those communities. Thus, the SQS method can be

85 used for estimating relative variation of biodiversity.

86 Ichnodiversity, however, cannot be analyzed by established methods for

87 biodiversity described above. Although these methods require the number of individuals of

88 each taxon for obtaining rarefaction curves or values of sample coverage, it is difficult to

89 count the number of individuals of ichnofossils because of their morphological

90 characteristics. The apparent number of ichnofossil specimens strongly depends on their

91 structural organization. Ichnofossils that appear as discrete scattered spots are counted as

92 large numbers, whereas those which make connected networks appear as a single specimen,

93 even though they are extremely large in size. For example, planar-formed, regular network

94 graphoglyptids such as Megagrapton or Paleodictyon may be preserved as multiple spots

95 on the bottom of a single sandstone bed. However, it is almost impossible to judge if

96 multiple spots on a bedding plane actually represent multiple individuals or fragments of a

97 single specimen. Even if there is intact preservation, it is difficult to recognize a single

98 individual from planar-formed ichnofossils that occupy very large areas of the bedding 
99 plane because the exposed region of the ichnofossil may represent only a part of the entire 100 morphology of an individual specimen.

101 In previous studies dealing with ichnodiversity, most authors attempted to

102 attenuate the effect of the outcrop exposure and observe the bedding plane as large as

103 possible (e.g., Heard and Pickering 2008; Cummings and Hodgson 2011). In this approach,

104 there is no criterion to judge if the area of observed outcrops is adequate for fair evaluation

105 of ichnodiversity. Recently, three different methods were applied for evaluating

106 ichnodiversity: the rarefaction method (Buatois et al. 2016), the ichnoabundance method

107 (Knaust et al. 2014), and the Gini Index method (Gianetti and McCann 2010). These

108 methods require the relative abundance of each ichnotaxon, which was estimated from the

109 numbers reported previously (Buatois et al. 2016) or apparent numbers of sections of

110 tubular structures on the bedding planes. However, as mentioned above, these

111 methodologies are not suitable for estimating the abundance of ichnofossils at outcrop scale.

112 In addition, the two methods described above are known to be problematic for estimation of

113 biodiversity (Alroy 2010c; Chao and Jost 2012). Thus, methods for assessing ichnofossil

114 diversity are not yet well established.

115 We propose a new method to evaluate ichnodiversity, independent of exposed area

116 of outcrops, by using an image-resampling technique with the application of the SQS

117 method. This method is applicable to images such as vertical successions, top or bottom

118 surfaces of beds, or polished sections of sedimentary rocks. In this method, (1) the

119 relationship between observed and detected numbers of ichnotaxa is obtained by

120 subsampling from existing outcrop or polished section images; (2) the coverage parameter 
121 of the sampled number of ichnotaxa and real ichnodiversity is then estimated from the fit

122 curve of subsampled data; and (3) the sample diversity of ichnotaxa is calculated from a

123 given value of the coverage parameter. We verified the method by applying it to artificial

124 data of ichnoassemblages. In this test, effects of variation on distribution patterns of

125 ichnofossils on bedding planes and shortage of outcrop exposure areas were examined.

126 Finally, we applied the new method to field data obtained from the Oligocene submarine

127 channel-levee complex to provide the first example of ichnological data independent of

128 outcrop exposure bias.

METHODOLOGY OF IMAGE-RESAMPLING

131 We named this method "Measurement of Ichnofossil Diversity by

132 Image-Resampling Technique” (MIDIRT) (Fig. 1). The step-wise procedure of this method 133 is listed below.

137 First, outcrop photographs are taken in the field or laboratory. The photographs should be 138 taken at random and perpendicular to the outcrop surfaces containing ichnofossils.

139 Ichnofossils may be observable on various types of surfaces, such as bottom surfaces of 140 sandstone beds or polished sections. This methodology is applicable for any type of surface,

141 but only photographs of the same type of surface can be compared with each other.

142 Additionally, photographs should not be taken to preferentially show specific ichnotaxa. 


\section{Identification of Ichnotaxa}

Each ichnotaxon is identified from the acquired outcrop images. The regions of

146 ichnofossils in images are colored with a specific grayscale or RGB color value for each

147 ichnotaxon, and regions where ichnofossils are absent are colored white. Regions outside

148 the outcrop surfaces are colored black.

\section{Image Resampling}

The line-of-interest in data resampling is randomly set in the acquired outcrop

152 image. If the resampling line protrudes from the outcrop, the line turns up to the next row

153 of pixels. The number of ichnotaxa on the line is then counted. As the length of the

154 resampling line $(L)$ increases, the number of counted ichnotaxa $\left(N_{\text {is }}\right)$ is expected to increase.

155 The length of the resampling line $(L)$ ranges from one to the maximum value of outcrop

156 area. For each length, the resampling process is repeated 100 times, and then the mean

157 value of $N_{\text {is }}\left(\overline{N_{\text {is }}}\right)$, is regarded as the representative value of the resampled data at the

158 given resampling length. This value shows the expected number of ichnotaxa when the

159 outcrop is explored by the resampling line that is $L$ in length.

163 observed length and number of ichnotaxa. Alroy $(2010 \mathrm{~b}, 2010 \mathrm{c})$ attempted to estimate the

164 sample coverage, which was expressed by the sum of the frequencies of taxa that 
165 hypothetical populations included, from chances of occurrence of undiscovered taxa using

166 Good-Turing estimation (Good 1953). This implies that the completeness of the sample

167 (sample coverage) can be evaluated by differences between unity and chance of occurrence

168 of undiscovered taxa. Although the chance of occurrence of undiscovered taxa cannot be

169 directly measured, the ratio of the number of singletons in the sample when the relative

170 frequencies of each taxon are based on a binomial distribution can be approximated. In

171 addition, Chao and Jost (2012) indicated that sample coverage for biodiversity is equal to

172 the slope of the tangential line of rarefaction curves in that condition. For the analytical

173 calculation of the slope of tangential lines as an estimator of the chance of occurrence of

174 undiscovered taxa, we employed a fitting function to the resampled data. The chance of

175 occurrence of undiscovered taxa can be estimated from using differential calculus of the

176 fitting function. Although the observed number of ichnotaxa $\left(\overline{N_{\text {is }}}\right)$ increases as the

177 resampling length $(L)$ increases, the increasing rate of $\overline{N_{\text {is }}}$ is expected to decline

178 gradually. Therefore, we employed the following as the fitting function (Mauffrey et al.

179 2007):

$$
E_{\mathrm{s}}=a_{1} \ln \left(1+a_{2} L\right)
$$

181 where $E_{\mathrm{s}}$ denotes the expected number of ichnotaxa and $a_{1}$ and $a_{2}$ are fitting

182 coefficients. The parameter $a_{1}$ is a dimensionless variable, and $a_{2}$ denotes a coefficient

183 for describing an increase rate of observed numbers of ichnotaxa, which has a dimension of

184 the inverse number of the length scale. The obtained curve of Equation 1 can be regarded as

185 the equivalent of rarefaction curves of biodiversity. The residual standard error of the curve 
186 fitting is defined as follows:

$$
R_{\mathrm{se}}=\sqrt{\frac{1}{n-p} \sum_{i=1}^{n} R_{i}{ }^{2}}
$$

188 where $n$ and $p$ denote the number of data points and fitting coefficients ( $p=2$ in this study),

189 respectively; $n-p$ represents degrees of freedom; and $R_{i}$ is the residual of the $i$ th data

190 point. Thus, $R_{\mathrm{se}}$ indicates the average distance of the data points from the fitted curve,

191 which can be interpreted as the goodness of fit of the curve. Although there is no certain

192 criterion for $R_{\mathrm{se}}$, an excessively large $R_{\mathrm{se}}$ (i.e. $>1$ ) implies that the assumption of the

193 methodology may be violated. Therefore, application of the method should be reconsidered

194 in such cases.

\section{Estimation of Ichnodiversity}

199 any given $L\left(S_{L}\right)$ is calculated as follows:

$$
S_{L}=\frac{a_{1} a_{2}}{1+a_{2} L}
$$

201 Chao and Jost (2012) argued that the sample coverage $(C)$ can be estimated as follows:

$$
C=1-S_{L}
$$

203 The sample coverage $(C)$ becomes 1 when sampled diversity is equivalent to the real

204 diversity, and thus the slope of the rarefaction curve is zero, and is expected to be positive

205 because the parameter $C$ is the proportion of the total number of individuals in the 
207 less than 1, so that $C$ may be negative when Equation 4 is used. Therefore, the slope $S_{L}$ is

208 normalized by the slope of Equation 1 at $L=0 \quad\left(S_{0}\right)$ :

209

$$
\overline{S_{L}}=\frac{S_{L}}{a_{1} a_{2}}
$$

210 For the biodiversity rarefaction curve, the number of taxa always becomes one when the

211 first specimen is sampled, and thus the slope of the discretized biodiversity rarefaction

212 curve is 1 at the interval where the number of samples is from 0 to 1 . Because of the

213 normalization represented by Equation 5, the normalized slope of Equation 1 becomes 1 at

$214 L=0$. Here the ichnotaxa coverage parameter $\bar{C}$ is defined as follows:

$$
\bar{C}=1-\overline{S_{L}}
$$

216 The parameter $\bar{C}$ becomes the minimum value 0 when $L=0$, and converges to 1 as $L$

217 increases. Equation 6 can be recalculated as:

$$
\bar{C}=\frac{a_{2} L}{1+a_{2} L}
$$

219 Equation 1 is recalculated as follows, with the aid of Equation 7:

$$
E_{\mathrm{s}}=a_{1} \ln \left(1+\frac{\bar{C}}{1-\bar{C}}\right)
$$

221 Equation 8 indicates that the ratio of $E_{\mathrm{s}}$ between two samples at any given $\bar{C}$ is always

222 constant. Consequently, fluctuation of the ichnodiversity in the outcrop image data at any

223 given ichnotaxa coverage parameter is obtained independent of differences in the exposed 
224 area of outcrops.

\section{VERIFICATION OF METHODOLOGY}

228 ichnoassemblages to verify the methodology, specifically the effects of distribution patterns

229 of ichnofossils on bedding planes and shortage of outcrop exposure area. Four artificial

230 outcrop images were produced with different distribution patterns and various types of

231 ichnofossils. In addition, incomplete outcrop images were also produced by gradually

232 decreasing the area of these four outcrop images. Then, the ichnodiversity estimated from

233 the artificial images was compared with the true values for methodology verification.

\section{Artificial Data}

236 Artificial ichnofossil images were allocated on virtual bedding planes to generate

237 artificial outcrop images showing ichnoassemblages. Chance of occurrence of each

238 ichnotaxon was set to the prescribed value (Fig. 2). In this series of experiments, two types

239 of spatial distribution patterns of ichnofossils were examined: uniform and patchy

240 distributions. In addition, two types of maximum number of ichnotaxa were also examined

241 (10 and 5 ichnotaxa) (Fig. 3). The procedures of allocating the ichnofossil images were as

242 follows: (1) 150 ichnofossil images were chosen based on their chance of occurrence (Fig.

243 2). (2) Ichnofossil images were allocated onto a white colored image $(6000 \times 4500$ pixels $)$.

244 The coordinates of each ichnofossil image were determined by the following equation: 


$$
p_{\mathrm{p}}=\left(\frac{d_{\min }}{D}\right)^{2 k}
$$

246 where $p_{\mathrm{p}}$ denotes the probability of whether an ichnofossil image is allocated at a point

247 (p) that was chosen by a uniform random number; $D$ is a specific distance from the point

$248 \mathrm{p}(D=200$ pixels in this study $) ; d_{\min }$ is the minimum value of the distances between $\mathrm{p}$ and

249 other points the ichnofossil images were already allocated; and $k$ is a coefficient that

250 determines the distribution pattern of the ichnofossil images $(k=-1,1)$. When $k=1$, the

251 point $\mathrm{p}$ that is far from other points in which the ichnofossil images were already allocated

252 tends to be adopted, and thus the distribution pattern becomes uniform. In contrast, when

$253 k=-1$, the point $\mathrm{p}$ that is close to other points tends to be adopted so that the ichnofossil

254 images are allocated in proximity with each other and the patchy distribution pattern is

255 established. Resolution of each image was set at 50 pixels/cm, thus, the maximum area of

256 the outcrop images was $10,800 \mathrm{~cm}^{2}$. All ichnofossil images were $100 \times 100$ pixels $(2 \times 2$

$257 \mathrm{~cm})$.

These outcrop images were then partially and progressively covered by black

259 coloration to produce images of the reduced areas, which were analyzed in order to verify

260 the effects on areas with outcrop exposure.

\section{Results}

264 repetitions of the resampling process, the mean number of observed ichnotaxa $\left(\overline{N_{\text {is }}}\right)$ 
265 against each length of the resampling line $(L)$ was estimated. The $95 \%$ confidence intervals

266 for each $\overline{N_{\text {is }}}$ were calculated by bootstrapping, replicating 10,000 times, with normal

267 approximation. Confidence intervals of the estimated numbers of ichnotaxa were larger in

268 patchy distribution patterns than in uniform distribution patterns. For all distribution

269 patterns, the estimated numbers of ichnotaxa increased as the lengths of resampling lines

270 increased, and they approached their maximum numbers of ichnotaxa when the resampling

271 lines filled the whole outcrop images. As a whole, the relationship between the lengths of

272 resampling lines and the estimated number of ichnotaxa were well-fitted to the function

273 expressed in Equation 1. Parameters of curve fitting are summarized in Table 1.

274 As a result of analyses, the fitting coefficients $a_{1}$ and $a_{2}$ were estimated as

275 follows, respectively: 1.726 and 0.036 in the uniform distribution with 10 ichnotaxa; 0.835

276 and 0.047 in the uniform distribution with 5 ichnotaxa; 1.797 and 0.029 in the patchy

277 distribution with 10 ichnotaxa; and 0.900 and 0.031 in the patchy distribution with 5

278 ichnotaxa (Table 1). Using these values, the coverage parameters $(\bar{C})$ were calculated. The

279 relationships between the coverage parameters $(\bar{C})$ and the expected numbers of ichnotaxa

$280\left(E_{\mathrm{s}}\right)$ are shown in Fig. 5. The shapes of curves, which were based on data of equivalent

281 maximum number of ichnotaxa, were similar to each other. Ratios of $E_{\mathrm{s}}$ among artificial

282 data are shown in Table 2.

283 The results of the numerical experiments for reduced outcrop exposure are shown

284 in Figure 6 and Table 1. The shapes of the $\bar{C}$-based ichnofossil rarefaction curves were

285 well maintained if the exposure area decreased, especially in diverse artificial data (uniform 
and patchy distribution patterns with 10 ichnotaxa) (Fig. 6A, C). In contrast, the $E_{\mathrm{s}}$ in the

case with 5 ichnotaxa tended to be under- or overestimated when the total exposure area was smaller than $50 \%$ of the original image (Fig. $6 \mathrm{~B}$, D; Table 1).

\section{APPLICATION TO FIELD DATA}

The MIDIRT method was applied to the field data measured in deposits of the

submarine channel-levee complex in the Oligocene Izaki Olistolith of the Nichinan Group (Sakai et al. 1987). The variation of ichnodiversity in the channel-fill deposit and the levee deposit was evaluated with MIDIRT.

\section{Geological Setting} southeastern part of Kyushu, southwestern Japan (Fig. 7). The Nichinan Group is composed

299 of various sized coherent blocks and intensely deformed beds. They are interpreted as the

300 deposits of the olistostrome which was caused by gravitational instability from the restart of 301 subduction of the Philippine Sea plate in 21-17 Ma (Sakai 1988a, 1988b, 1988c). The Izaki

302 Olistolith distributed in Izaki-bana is considered as one of the coherent blocks that were 303 originally deposited in the deep-sea setting (Sakai et al. 1987) (Fig. 7). It is mainly

304 composed of alternating beds of turbidite sandstone and mudstone and is interpreted to be a 305 deposit of a submarine channel-levee complex (Yumi and Ishihara 2012). The Izaki

306 Olistolith can be divided into three stratigraphic units based on lithology. The lower and 307 upper parts of the Izaki Olistolith (units A and C; Fig. 7D) are comprised of thin-bedded 
308 turbidite sandstone and mudstone beds. The sandstone beds in the units A and C are mainly

309 1-20 cm thick, and climbing ripple and convolute lamination are observable. The mudstone

310 beds are $10-20 \mathrm{~cm}$ thick. Taking this into consideration, the deposits of the units $\mathrm{A}$ and $\mathrm{C}$

311 are interpreted as submarine levee deposits (Arnott 2010). In contrast, the middle part of the

312 Izaki Olistolith (unit B; Fig. 7D) consists of thick-bedded turbidite sandstones and

313 thin-bedded mudstones. The thickness of the sandstone beds in the unit B ranges from 5 to

$314200 \mathrm{~cm}$. The current ripple, climbing ripple, convolute lamination, and parallel lamination

315 are observable on the top of sandstone beds. The sole marks, such as flute cast or groove

316 cast, are commonly found on the bottom surface of thick-bedded (more than $100 \mathrm{~cm}$ thick)

317 sandstone beds. The mudstone beds in the middle part are less than $10 \mathrm{~cm}$ thick. The

318 alternating beds in the unit B show an upward-thinning succession. These characteristics

319 indicate that the unit B of the Izaki Olistolith is the submarine channel-fill deposit (Arnott

320 2010).

Ichnoassemblage of the Izaki Olistolith

The ichnoassemblage in the Izaki Olistolith is mainly composed of graphoglyptids

324 (Fig. 8). This study investigated the number of ichnogenera and measured the exposed area

325 of the bottom surfaces of each turbidite sandstone bed. For the image-resampling method,

326 photographs of the bottom surfaces of sandstone beds were obtained through field work,

327 and then were colored appropriately for each ichnogenus. We observed 5,960 $\mathrm{cm}^{2}$ and

$32833,520 \mathrm{~cm}^{2}$ of bottom surfaces of the turbidite sandstone beds in the levee deposit and the

329 channel-fill deposit, respectively. 
A total of 11 ichnogenera were recognized on the sole surface of sandstone beds in

331 the levee deposit (Table 3). Abundant Phycosiphon incertum and Gordia marina are

332 characteristics of this deposit. Graphoglyptids, such as Megagrapton irregulare or

333 Paleodictyon strozzii, were rarely observed in relatively thin-bedded sandstones $(5-15 \mathrm{~cm}$

334 thick). In contrast, the thick-bedded sandstones (50-200 cm thick) contain fewer

335 ichnogenera even though the bottom surfaces of these beds are widely exposed.

336 A total of 22 ichnogenera were found on the sole surface of sandstone beds in the

337 channel-fill deposit (Table 3). Various types of graphoglyptids were observed in these

338 deposits. Helminthorhaphe japonica and Paleodictyon strozzii were common.

339 Desmograpton inversum, Punctorhaphe parallela, and Spirorhaphe involuta are rarely

340 observed. Thick-bedded sandstones in the lower part of the channel-fill deposits (unit B1;

341 Fig. 7D) yielded fewer ichnogenera, whereas various ichnogenera occurred in the upper

342 part (unit B2; Fig. 7D).

Results

345 Results of our image-resampling method are summarized in Fig. 9. As with the

346 artificial data, the numbers of ichnogenera in each sedimentary environment increased as

347 observed area increased. The plots were well-fitted to Equation 1. The residual standard

348 error $\left(R_{\mathrm{se}}\right)$ was 0.180 in the channel-fill deposit and 0.300 in the levee deposit (Table 4).

349 The fitting coefficients $a_{1}$ and $a_{2}$ in the channel-fill deposit were 4.916 and

$350 \quad 0.003$, respectively. In contrast, those in the levee deposit were 2.825 and 0.007 ,

351 respectively (Table 4). Using these values, the coverage parameters $(\bar{C})$ were calculated. 
352 The relationship between the coverage parameters $(\bar{C})$ and the expected numbers of

353 ichnotaxa $\left(E_{\mathrm{s}}\right)$ were then estimated (Fig. 10). $E_{\mathrm{s}}$, when $\bar{C}=0.8$ in the channel-fill and

354 levee deposits was 7.913 and 4.547, respectively. Therefore, the ichnodiversity in the

355 channel-fill deposit was 1.740 times higher than in the levee deposit.

This study employed Equation 1 as the fitting function of the rarefaction curves,

360 according to Mauffrey et al. (2007). Mauffrey et al. (2007) used and evaluated three models,

361 which included the Exponential Dependence model (recast to Equation 1), Clench model,

362 and Linear Dependence model, to fit the individual-based rarefaction curves for species

363 richness extrapolation of the small-mammal communities in a French Guianan rainforest.

364 They concluded that Equation 1 was the most suitable for extrapolation of the rarefaction

365 curves because the estimated diversity based on Equation 1 showed the most similar value

366 to the known local biodiversity in their study area based on previous trapping missions,

367 although goodness of fit for these three models was not significantly different. In contrast,

368 van Rooijen (2009) estimated snake species richness of the Santubong Peninsula in Borneo

369 by extrapolating the individual-based rarefaction curve. He applied two exponential models

370 to fit the rarefaction curve, the negative exponential and Weibull functions. The Weibull

371 function was recast as the following equation:

372

$$
Y=A(1-\exp (b-c t))
$$


373 where $Y$ denotes the expected number of species; $A$ is total number of species; $t$ is sample

374 size; and $b$ and $c$ are constants that denote the ease which species are found. van Rooijen

375 (2009) argued that the Weibull function exhibited higher goodness of fit than the negative

376 exponential function, and expected species richness based on the Weibull function

377 corresponded with the value estimated by the Chao I estimator (Chao 1984). Therefore, he

378 concluded that the Weibull function is suitable for extrapolation of the rarefaction curve.

379 For ichnodiversity, there are some problems in fitting the Weibull function to the

380 relationship between $L$ and $E_{\mathrm{s}}$. First, goodness of fit of the Weibull function is lower than

381 that of Equation 1. The Akaike's Information Criterion (AIC) for the uniform distribution

382 with 10 ichnotaxa was 24.44 when fitted to the Weibull function, whereas 1.38 when fitted

383 to Equation 1. Figure 11 shows the result of fitting the Weibull function for uniform

384 distribution with 10 ichnotaxa. The fitted Weibull function tended to overestimate when $L$

385 was an intermediate value (approximately 4,000 to $5,000 \mathrm{~cm}$ ) and underestimate when $L$

386 was small or large (Fig. 11). Second, the asymptote of the Weibull function $(Y=A)$ strongly

387 depended on the observed maximum number of ichnotaxa. The maximum number of

388 ichnotaxa estimated by the fitted Weibull function was 9.701 for $100 \%$ exposed artificial

389 data of the uniform distribution with 10 ichnotaxa. In contrast, it was 8.224 in for $50 \%$

390 exposed data in which exactly 8 ichnotaxa were observed. Therefore, estimation using the

391 Weibull function is unsuitable to correct outcrop exposure bias.

392 Application of Equation 1 leads an infinite value of ichnodiversity when $L \rightarrow \infty$

393 or $\bar{C}=1$ because Equation 1 does not have an asymptote (eq. 1 and 8). This implies that

394 ichnodiversity in the hypothetical population cannot be estimated by extrapolation of 
395 Equation 1. However, $E_{\mathrm{s}}$ standardized by $\bar{C}$ in the interpolation interval can be

396 compared fairly, regardless of the difference in distribution pattern and outcrop exposure

397 bias (see below for discussion). Furthermore, the ratio of $E_{\mathrm{s}}$ among any two datasets was

398 always constant at any given $\bar{C}$ (eq. 8). Taking this into consideration, Equation 1 is valid 399 as the fitting function for the relationship between $L$ and $E_{\mathrm{s}}$, if the analysis aim is

400 comparison of $E_{\mathrm{s}}$ in the interpolation interval and not extrapolation.

404 the MIDIRT is a valuable method to evaluate ichnodiversity regardless of outcrop exposure 405 area, the total number of ichnotaxa, or distribution patterns of ichnofossils on the bedding 406 planes. Each $\bar{C}$-based fitting curve of artificial data corresponded to another curve which 407 had an equal maximum number of ichnotaxa (Fig. 5). As the $\bar{C}$-based fitting curves are the 408 logarithmic functions passing an origin (eq. 8), ratios of $E_{\mathrm{s}}$ in each artificial image are 409 constant even if $E_{\mathrm{s}}$ is normalized at any ichnotaxa coverage parameter. For example, the 410 ratio of $E_{\mathrm{s}}$ in the uniform distribution pattern with 10 ichnotaxa and uniform distribution 411 pattern with 5 ichnotaxa was constantly 2.067 (Table 2 ). In contrast, the ratio of the 412 maximum numbers of ichnotaxa in these conditions was 2.000. Therefore, it was

413 considered that the ratio of $E_{\mathrm{s}}$ was reflected in the maximum numbers of ichnotaxa in 414 each condition. In other combinations of conditions, the ratio of $E_{\mathrm{s}}$ also showed the same 
415 tendency (Table 2). The $\bar{C}$-based fitting curves showed that $E_{\mathrm{s}}$ obtained from the images

416 showing patchy distribution patterns with 10 ichnotaxa were slightly overestimated when

417 compared with $E_{\mathrm{s}}$ in conditions with equivalent maximum number of ichnotaxa (Fig. 5;

418 Table 2). The increasing rate of observed number of ichnotaxa $\left(a_{2}\right)$ in the patchy

419 distribution with 10 ichnotaxa was smaller than that of other conditions (Table 1). This was

420 likely due to a larger area of bedding plane in which no ichnotaxa were observed, and thus,

$421 \bar{C}$ at a given $L$ was also smaller. This may have led to the overestimation of $E_{\mathrm{s}}$ in the

422 patchy distribution with 10 ichnotaxa. However, differences between the ratios of $E_{\mathrm{s}}$ and

423 that of the maximum numbers of ichnotaxa were small enough to disregard. These results

424 indicate that ichnodiversity can be compared fairly, independent of outcrop exposure bias

425 using MIDIRT.

We tested our methodology to the outcrops of the channel-levee system in the

429 Izaki Olistolith, and suggested that the effect of outcrop exposure bias cannot be ignored.

430 The result of our method shows that the ratio of $E_{\mathrm{s}}$ in the channel-fill deposit and levee

431 deposit is 1.740 although that of the raw numbers of ichnotaxa is higher value (2.000). In

432 the case of the Izaki Olistolith, the channel-fill deposits expose better than the levee

433 deposits, which leads to the apparently larger ichnodiversity. The decrease in the ratio of

434 the ichnodiversity indicates that, therefore, our method corrected this bias.

435 In general, however, it is estimated that the ichnodiversity in channel-fill deposits 
436 tends to be underestimated than in levee deposits. The number of observable beds in a

437 certain interval is generally larger in levee deposits than in channel-fill deposits because

438 levee deposits are composed of thin-bedded turbidite sandstone beds in which erosive

439 bottom surfaces are rare. On the other hand, channel-fill deposits are dominated by

440 thick-bedded turbidite sandstone beds which often show amalgamated bottom surfaces.

441 Therefore, the observed number of ichnotaxa in channel-fill deposits is expected to be

442 smaller than in levee deposits. This kind of outcrop exposure bias in each sedimentary

443 environment may have not been adequately considered in previous studies, and therefore

444 our methodology is significant for evaluating not only the temporal variation of the

445 paleoenvironments but also the comparison of ichnodiversities over various lithofacies.

446 In contrast, it is generally considered that the repeated scouring on channel floors

447 may negatively affect the establishment of K-selected populations such as those responsible

448 of producing graphoglyptids (e.g. Heard and Pickering 2008; Cummings and Hodgson

449 2011; Heard et al. 2014). It implies a possibility that the higher ichnodiversity in

450 channel-fill deposits than that of levee deposits may be a peculiar phenomenon in the Izaki

451 Olistolith. Further investigations of ichnodiversity in channel-levee complexes independent

452 of outcrop exposure bias will clarify the inconsistency between the trend in previous works 453 and that in the Izaki Olistolith.

Future application of the method

Further application of our method to ichnological data around the world will reveal

457 the paleoenvironmental variation through the evaluation of the ichnodiversity eliminating 
458 the effect of observation bias. Wetzel (1991) suggested that pore water oxygenation level

459 and benthic food content strongly affect ichnodiversity. Cummings and Hodgson (2011)

460 argued that fluctuation in number of ichnotaxa in submarine fan deposits of the Basque

461 Basin, northern Spain was induced by dysoxic/anoxic conditions. In addition, biodiversity

462 of benthic communities can be affected by benthic food content on the seafloor. For

463 instance, it is well known that biodiversity increases are associated with decreasing organic

464 matter input, whereas biodiversity decreases in oversupplied organic matter conditions (P-R

465 model; Pearson and Rosenberg 1978). However, ichnodiversity does not directly

466 correspond with benthic biodiversity (Buatois and Mángano 2013), so that further

467 examination is needed for understanding relationship between benthic food content and the 468 resultant variation in ichnodiversity.

469 Although there are some issues and room for development, the MIDIRT method is

470 applicable for both characterizing depositional facies and temporal variations of

471 ichnodiversity. There have been attempts to construct the model for estimation of

472 paleoenvironmental conditions based on fluctuation of ichnodiversity (e.g. Heard and

473 Pickering 2008; Cummings and Hodgson 2011; Phillips et al. 2011; Callow et al. 2013).

474 These models will be more reliable with fair comparison of ichnodiversity by the MIDIRT 475 method.

\section{CONCLUSIONS}

478 We proposed a new method, MIDIRT, to evaluate ichnodiversity from outcrop

479 records. Although the number of ichnotaxa is generally affected by outcrop exposure bias, 
480 existing methods to correct sample size bias cannot be applied to ichnofossil analyses as the

481 relative abundance of ichnofossils is difficult to measure because of the variations in

482 morphological characteristics. The method we proposed corrects this bias by using an

483 image-resampling technique combined with the SQS method (Alroy 2010b, 2010c). The

484 method was verified by applying it to four types of artificial data. As a result, the ratio of

485 the estimated sample ichnodiversity approximated the ratio of the real ichnodiversity with

486 each dataset. Results also suggested that ichnodiversity can be compared fairly, regardless

487 of area of outcrop exposure and distribution patterns of ichnofossils on the bedding planes.

488 The method was also applied to field data of the ichnoassemblage in the channel-levee

489 complex of the Oligocene Izaki Olistolith of the Nichinan Group. The result of the analysis

490 indicated that ichnodiversity, independent of outcrop exposure bias, was higher in the

491 channel-fill deposit than the levee deposit. In contrast, previous studies showed an inverse

492 trend of increasing ichnodiversity from channel-axial to marginal environments. Evaluation

493 of ichnodiversity by the MIDIRT method is expected to be useful in reconstructing

494 paleoenvironmental conditions.

ACKNOWLEDGEMENTS

Takao Ubukata (Kyoto University) provided useful comments on statistics and

498 body fossil diversity. The paper benefited from constructive reviews by two anonymous

499 referees, as well as from numerous editorial comments by M. Gabriela Mángano. A part of

500 this study was supported by a grant from the Fukada Geological Institute (2014). All these

501 contributions are gratefully acknowledged. 


\section{REFERENCES}

504 AlROY, J., 2010a, The shifting balance of diversity among major marine animal groups:

505 Science, v. 329, p. 1191-1194, doi: 10.1126/science.1189910.

506 Alroy, J., 2010b, Geographical, environmental and intrinsic biotic controls on Phanerozoic

507 marine diversification: Paleontology, v. 53, p. 1211-1235, doi: 10.1111/j.1475-4983.2010.01011.x.

509 Alroy, J., 2010c, Fair sampling of taxonomic richness and unbiased estimation of 510 origination and extinction rates, in J. Alroy and G. Hunt (eds.), Quantitative Methods 511 in Paleobiology: The Paleontological Society, Boulder, p. 55-80.

512 ARNOTT, R.W.C., 2010, Deep-marine sediments and sedimentary system, in N.P. James and 513 R.W. Dalrymple (eds.), Facies Models 4, Geological Association of Canada, St. John's, $514 \quad$ NL, Canada, p. 295-322.

515 Bayet-Goll, A., Neto de Carvalho, C., Mahmudy-Gharaei, M.H., And Nadaf, R., 5162015 , Ichnology and sedimentology of a shallow marine Upper Cretaceous 517 depositional system (Neyzar Formation, Kopet-Dagh, Iran): palaeoceanographic 518 influence on ichnodiversity: Cretaceous Research, v. 56, p. 628-646, doi: $519 \quad$ 10.1016/j.cretres.2015.07.008.

520 Bromley, R.G. ANd Ekdale, A. A., 1984, Chondrites: a trace fossil indicator of anoxia in 521 sediments: Science, v. 224, p. 872-875, doi: 10.1126/science.224.4651.872.

522 BUATOIS, L.A. and MÁNGANO, M.G., 2013, Ichnodiversity and ichnodisparity: significance 523 and caveats: Lethaia, v. 46, p. 281-292, doi: 10.1111/let.12018. 
524 Buatois, L.A., MAngano, M.G., And MaPles, C.G., 1997, The paradox of nonmarine

525 ichnofaunas in tidal rhythmites; intergrating sedimentologic and ichnologic data from

526 the Late Cretaceous of eastern Kansas, USA: PALAIOS, v. 12, p. 467-481, doi:

527 $10.2307 / 3515384$.

Buatois, L.A., MÁngano, M.G., Olea, R.A., and Wilson, M.A., 2016, Decoupled evolution of soft and hard substrate communities during the Cambrian Explosion and Great Ordovician Biodiversification Event: Proceedings of the National Academy of Sciences, v. 113, p. 6945-6948, doi: 10.1073/pnas.1523087113.

Callow, H.T.R., Kneller, B., DyKstra, M., and McLlroy, D., 2014, Physical, biological, geochemical and sedimentological controls on the ichnology of submarine canyon and slope channel systems: Marine and Petroleum Geology, v. 54, p. 144-166, doi:

Callow, H.T.R., MCIlroy, D., Kneller, B., and DyKSTRA, M., 2013, Integrated Petroleum Geology, v. 41, p. 277-294, doi: 10.1016/j.marpetgeo.2012.02.001.

ChaO, A. and Jost, L., 2012, Coverage-based rarefaction and extrapolation: standardizing samples by completeness rather than size: Ecology, v. 93, p. 2533-2547, doi: $10.1890 / 11-1952.1$

543 CHAO, A., 1984, Nonparametric estimation of the number of classes in a population: 544 Scandinavian Journal of Statistics, v. 11, p. 265-270, doi: 10.2307/4615964. 545 Cummings, J.P. and Hodgson, D.M., 2011, Assessing controls on the distribution of 
546 ichnotaxa in submarine fan environments, the Basque Basin, Northern Spain:

547 Sedimentary Geology, v. 239, p. 162-187, doi: 10.1016/j.sedgeo.2011.06.009.

548 GiannetTi, A. AND MCCANN, T., 2010, The upper Paleocene of the Zumaya section

549 (northern Spain): review of the ichnological content and preliminary palaeoecological

550 interpretation: Ichnos, v. 17, p. 137-161, doi: 10.1080/10420941003659550.

551 Gingras, M.K., MacEACHERn, J.A., AND Dashtgard, S.E., 2011, Process ichnology and

552 the elucidation of physico-chemical stress: Sedimentary Geology, v. 237, p. 115-134,

553 doi: 10.1016/j.sedgeo.2011.02.006.

554 GoOD, I.J., 1953, The population frequencies of species and the estimation of population

555 parameters: Biometrika, v. 40, p. 237-264, doi: 10.1093/biomet/40.3-4.237.

556 Hauck, T., Dashtgard, S.E., Pemberton, S.G., And Gingras, M.K., 2009,

557 Brackish-water ichnological trends in a microtidal barrier island-embayment system,

558 Kouchibouguac National Park, New Brunswick, Canada: PALAIOS, v. 24, p. 478-496,

559 doi: 10.2110/palo.2008.p08-056r.

560 HeARD, T.G. and PICKERING, K.T., 2008, Trace fossils as diagnostic indicators of

561 deep-marine environments, middle Eocene Ainsa-Jaca basin, Spanish Pyrenees:

562 Sedimentology, v. 55, p. 809-844, doi: 10.1111/j.1365-3091.2007.00922.x.

563 HEARD, T.G., PICKERING, K.T., and ClARK, J.D., 2014, Ichnofabric characterization of a

564 deep-marine clastic system: a subsurface study of the middle Eocene Ainsa System,

565 Spanish, Pyrenees: Sedimentology, v. 61, p. 1298-1331, doi: 10.1111/sed.12101.

566 HURLBERT, S.H., 1971, The nonconcept of species diversity; a critique alternative

567 parameters: Ecology, v. 52, p. 577-586, doi: 10.2307/1934145. 
568 Hyland, J., Balthis, L., Karakassis, I., Magni, P., Petrov, A., Shine, J., Vestergaard,

569 O., AND WARWICK, R., 2005, Organic carbon content of sediments as an indicator of

$570 \quad$ stress in the marine benthos: Marine Ecology Progress Series, v. 295, p. 91-103, doi: $10.3354 / \operatorname{meps} 295091$.

KNAUST, D., 2007, Invertebrate trace fossils and ichnodiversity in shallow-marine carbonates of the German Middle Triassic (Muschelkalk), in R.G. Bromley, L.A. Buatois, M.G. Mángano, J.F. Genise, and R.N. Melchor (eds.), Sediment-Organism Interactions: A Multifaceted Ichnology: SEPM Special Publication, v. 88. p. 221-238. 2218-2267, doi: 10.1111/sed.12134.

Mauffrey, J. F., Steiner, C. And CATZEFlis, F. M., 2007, Small-mammal diversity and abundance in a French Guianan rain forest: test of sampling procedures using species rarefaction curves: Journal of Tropical Ecology, v. 23, p. 419-425, doi: $10.1017 / \mathrm{S} 0266467407004154$.

ORR, P. J., 2001, Colonization of the deep-marine environment during the early Phanerozoic: the ichnofaunal record: Geological Journal, v. 36, p. 265-278, doi: 10.1002/gj.891.

PeARSON, T.H. AND RosenberG, R., 1978, Macrobenthic succession in relation to organic enrichment and pollution of the marine environment: Oceanography and Marine Biology: An Annual Review, v. 16, p. 229-311.

Phillips, C., McIlroy, D., and ElLiOTT, T., 2011, Ichnological characterization of 
590 Eocene/Oligocene turbidites from the Grès d'Annot Basin, French Alps, SE France:

591 Palaeogeography, Palaeoclimatology, Palaeoecology, v. 300, p. 67-83, doi: 10.1016/j.palaeo.2010.12.011.

593 SAKAI, H., 1988a, Toi-misaki olistostrome of the southern belt of the Shimanto Terrane, 594 south Kyushu-I. Reconstruction of depositional environments and stratigraphy 595 before collapse: Journal of Geological Society of Japan, v. 94, p. 733-747, doi: 10.5575/geosoc.94.733. (In Japanese).

597 SAKAI, H., 1988b, Toi-misaki olistostrome of the southern belt of the Shimanto Terrane, south Kyushu - II. Deformation structure of huge submarine slides and processes of formation: Journal of Geological Society of Japan, v. 94, p. 837-853 doi:

SAKAI, H., 1988c, Origin of the Misaki Olistostrome Belt and re-examination of the Takachiho Orogeny: Journal of Geological Society of Japan, v. 94, p. 945-961 doi:

SAKai, T., KusABA, T., Nishi, H., Komori, M., and WatanaBe, M., 1987, Olistostorome of the Shimanto Terrane in the Nichinan area, southern part of the Miyazaki Prefecture, south Kyushu — with reference to deformation and mechanism of emplacement of

609 SANDERS, H.L., 1968, Marine benthic diversity: a comparative study: The American

610 Naturalist, v. 102, p. 243-282, doi: 10.1086/282541.

611 Timmer, E.R., BotteriLl, S.E., Gingras, M.K., And Zonneveld, J.-P., 2016, Visualizing a 
612 process ichnology dataset, Lower Cretaceous McMurray Formation, NE Alberta,

613 Canada: Bulletin of Canadian Petroleum Geology, v. 64, p. 251-265, doi:

$614 \quad$ 10.2113/gscpgbull.64.2.251.

615 UCHMAN, A., 2003, Trends in diversity, frequency and complexity of graphoglyptid trace

616 fossils: evolutionary and palaeoenvironmental aspects: Palaeogeography,

617 Palaeoclimatology, Palaeoecology, v. 192, p. 123-142, doi:

$618 \quad 10.1016 / \mathrm{S} 0031-0182(02) 00682-\mathrm{X}$.

619 VAN RoOIJEN, J., 2009, Estimating the snake species richness of the Santubong Peninsula

620 (Borneo) in two different ways: Contributions to Zoology, v. 78, p. 141-147.

621 WeTZEL, A., 1991, Ecologic interpretation of deep-sea trace fossil communities:

622 Palaeogeography, Palaeoclimatology, Palaeoecology, v. 85, p. 47-69, doi:

$623 \quad 10.1016 / 0031-0182(91) 90025-\mathrm{M}$.

624 Wetzel, A., AND UChman, A., 1998, Deep-sea benthic food content recorded by

625 ichnofabrics; a conceptual model based on observations from Paleogene flysch,

626 Carpathians, Poland: Palaios, v. 13, p. 533-546, doi: 10.2307/3515345.

627 YUMI, M. AND ISHIHARA, Y., 2012, Characterization of erosional marks in the base of 628 sediment-gravity-flow deposits: special reference to the effect of flow duration for 629 flute mark formation: Journal of Sedimentological Society of Japan, v. 71 p. 173-190, 630 doi: $10.4096 /$ jssj.71.173.

632 Figure and Table Captions

633 FIG. 1.- Schematic diagram of Measurement of Ichnofossil Diversity by 
Image-Resampling Technique (MIDIRT) procedures. The procedures are as follows: is illustrated with a particular gray scale value in outcrop images; (3a) one of the outcrop images is selected at random, and (3b) the line of interest that has a given length $L$ is randomly set in the image. Then the number of types of gray scale values are counted along the line of interest; (3c) the processes of resampling (3a, b) are repeated 100 times, and the results are averaged for obtaining an expected number of ichnotaxa corresponding to the length of resampling line $L$. (4) The relationship between length of the line-of-interest (approximated to observed area) $L$ and expected number of ichnotaxa $E_{S}$ is estimated by repeating processes $(3 \mathrm{a}-\mathrm{c})$ with changing sampling length $L$; and (5) the coverage parameter, which is an estimate of

FIG. 2.- List of illustrated symbols of ichnofossils and their chance of occurrence.

FIG. 3.-Four artificial outcrop images that were generated for verification of the MIDIRT method proposed in this study. A) Uniform distribution pattern with 10 ichnotaxa. B) Uniform distribution pattern with 5 ichnotaxa. C) Patchy distribution pattern with 10

652 FIG. 4.- Relationships between resampling length and number of detected ichnotaxa, based 653 on analysis of artificial outcrop images by MIDIRT. Each plot represents the average 654 number of detected ichnotaxa that was obtained from 100 trials using the given resampling length. The fitted curves and coefficients of determination are also shown. 
656 Error bars indicate the $95 \%$ confidence intervals of the average numbers of detected

657 ichnogenera. A) Result from the image of uniform distribution pattern with 10

658 ichnotaxa. B) Result from the image of uniform distribution pattern with 5 ichnotaxa.

659 C) Result from the image of patchy distribution pattern with 10 ichnotaxa. D) Result

660 from the image of patchy distribution pattern with 5 ichnotaxa.

661 FIG. 5.-Expected number of ichnotaxa $E_{S}$ against the ichnotaxa coverage parameter used

662 in the MIDIRT method. Shapes of fitted curves for $E_{s}$ only depend on the actual

663 number of ichnotaxon, and are independent of spatial patterns of ichnofossil

664 distribution.

665 FIG. 6.- $\bar{C}$-based fitting curves of the artificial outcrop images showing the effect of

666 outcrop exposure bias based on the result of MIDIRT analysis. A) Uniform

667 distribution pattern with 10 ichnotaxa. B) Uniform distribution pattern with 5

668 ichnotaxa. C) Patchy distribution pattern with 10 ichnotaxa. D) Patchy distribution

$669 \quad$ pattern with 5 ichnotaxa.

670 FIG. 7.-Maps showing the study area. A) Location of study area. B) Geological map of the 671 southern part of the Nichinan coastal area, southern part of Kyushu, southwest Japan.

672 Modified after Sakai (1988c). C) Lithological map of the Izaki-bana. In addition to

673 coherent alternating beds of turbidite sandstone and mudstone, intensely deformed

674 slumped beds are widely distributed on the Izaki-bana. Various ichnofossils that

675 mainly comprised graphoglyptids are observable at the basal surfaces of turbidite beds.

676 D) Schematic columnar section of the Izaki Olistolith. Stratigraphic intervals and

677 interpretation of depositional environment are also shown. st: siltstone, vfs: very fine 
678 sandstone, fs: fine sandstone, ms: medium sandstone.

679 FIG. 8.-Ichnofossils occurring on the bottom surface of sandstone beds in the Izaki

680 Olistolith. A) Cosmorhaphe parva. B) Gordia marina. C) Helminthorhaphe japonica. D) Paleodictyon minimum (Pm) and P. strozzii (Ps). E) Punctorhaphe parallela. F) Spirophycus bicornis. Scale bar $=2 \mathrm{~cm}$.

FIG. 9.- Relationships between resampling lengths and number of ichnogenera obtained by the MIDIRT method applied to field data from the Izaki Olistolith. Each plot represents the average number of detected ichnogenera of 100 trials for each ichnogenera. A) Channel-fill deposits. B) Levee deposits.

689 FIG. 10.- Variation of expected number of ichnotaxa $E_{s}$ of the channel-fill deposits and the levee deposits in the Izaki Olistolith against the ichnotaxa coverage parameter.

691 FIG. 11. Comparison of two fitting functions with the artificial data of the uniform 692 distribution with 10 ichnotaxa.

693 TABLE. 1.-Coefficients of the curves fitted to the resampled data of the artificial outcrop 694 images, parameters showing goodness of fit, and ratio of ichnodiversity. The rightmost column represents ratios between ichnodiversity of each exposure condition and $100 \%$ exposed data in the same distribution patterns and maximum numbers of ichnotaxa.

697 TABLE. 2.- - Results comprising ratios of estimated numbers of ichnotaxa for artificial $698 \quad$ outcrop images.

699 TABLE. 3.- - List of ichnotaxa occurring on the bottom of sandstone beds in the Izaki 
$700 \quad$ Olistolith.

701 TABLE. 4. - Coefficients of the curves fitted to the resampled data of the field data of the

702 Izaki Olistolith and parameters showing goodness of fit. 
1. Acquisition of outcrop images
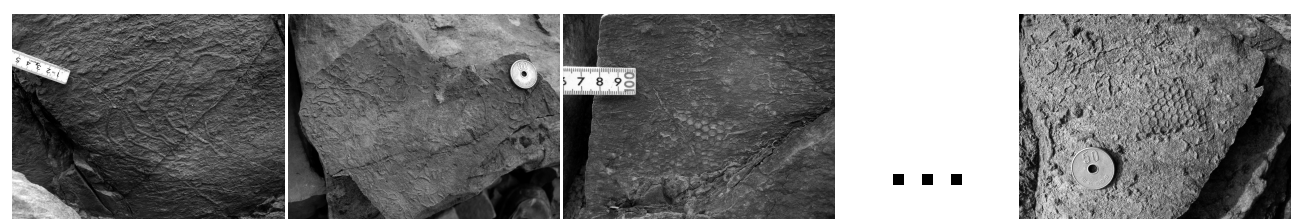

$\downarrow$ 2. Painting with paticular gray scale for each ichnotaxon

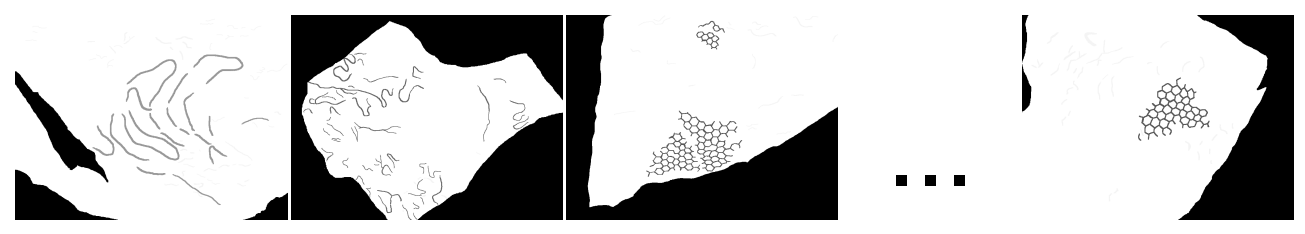

$\downarrow 3 a$. Selecting a image at random $\uparrow$ 3c. Repeating 100 times

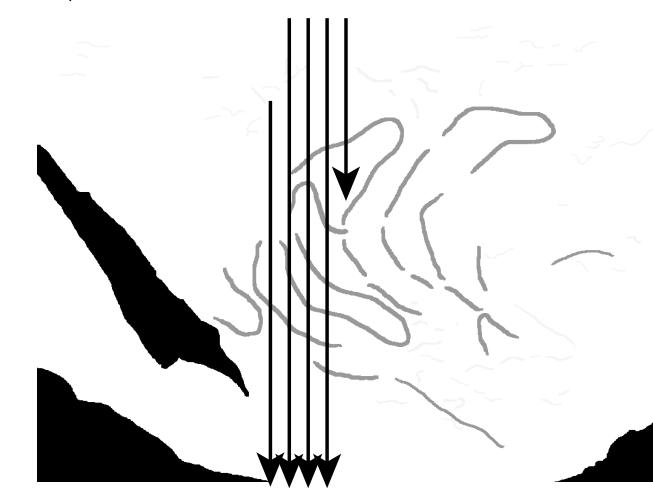

$3 b$. Counting kinds of gray scale value on the line-of-interest randomly set

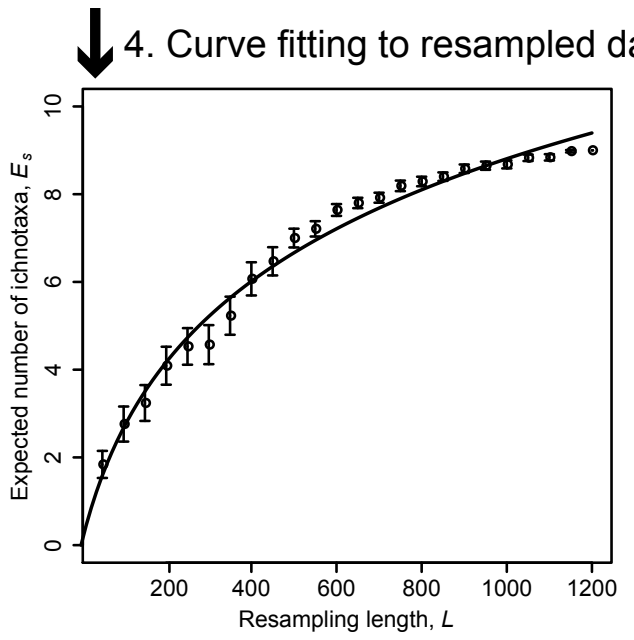

5. Estimation of ichnodiversity

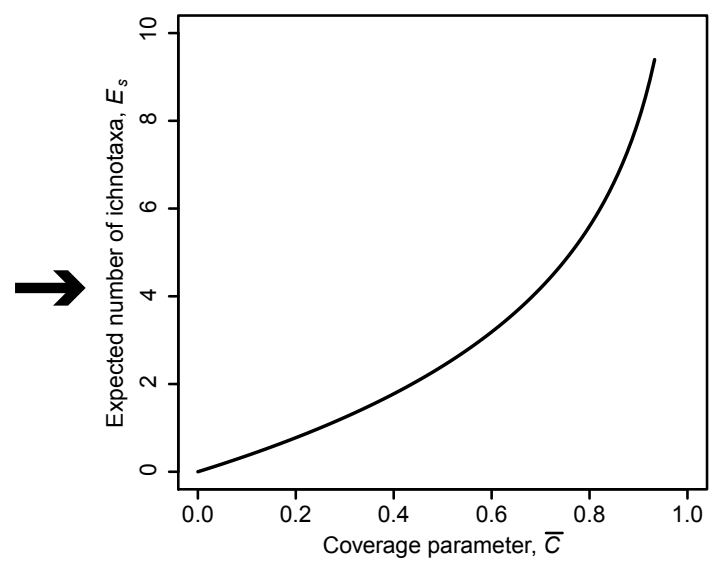

Fig. 1 


\begin{tabular}{ccc}
\hline Ichnofossil & \multicolumn{2}{c}{ Chances of occurrence } \\
\cline { 2 - 3 } images & High diversity & Low diversity \\
\hline \hline$A$ & 0.30 & 0.64 \\
$B$ & 0.20 & 0.23 \\
$C$ & 0.20 & 0.09 \\
$D$ & 0.10 & 0.03 \\
$E$ & 0.06 & 0.01 \\
$F$ & 0.05 & - \\
$G$ & 0.03 & - \\
$H$ & 0.03 & - \\
$I$ & 0.02 & - \\
$J$ & 0.01 & - \\
\hline
\end{tabular}

Fig. 2 
A

C

Fig. 3
B

D

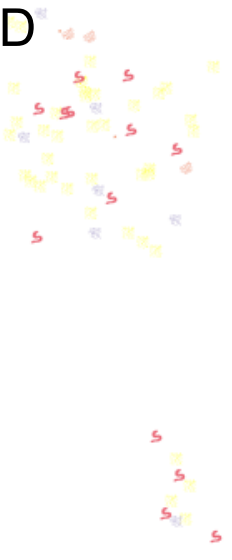

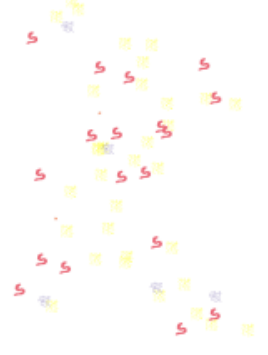

5 s 5 



Fig. 4 


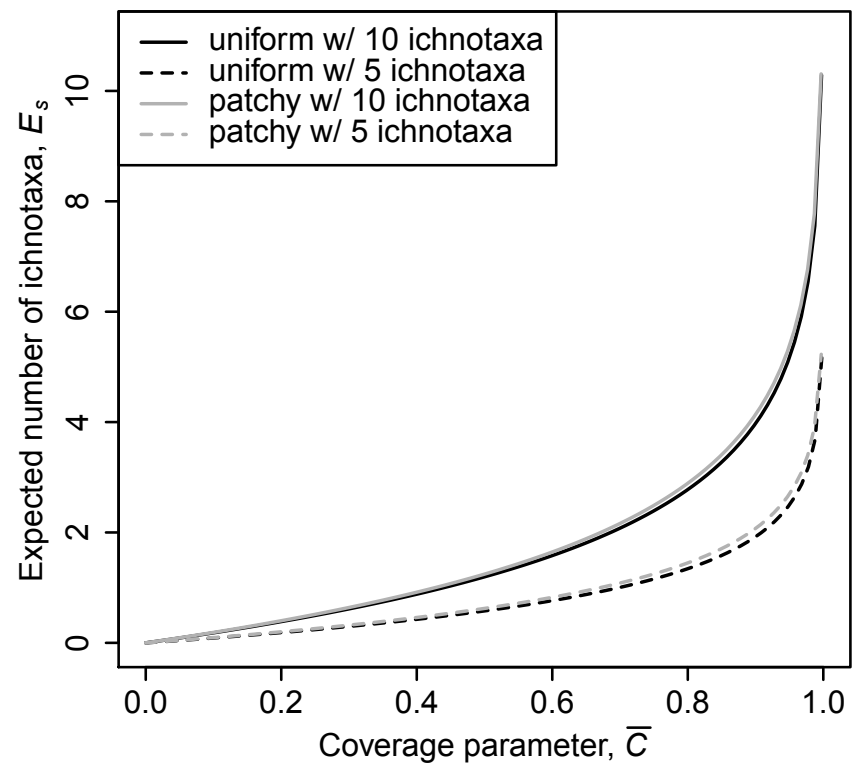

Fig. 5 

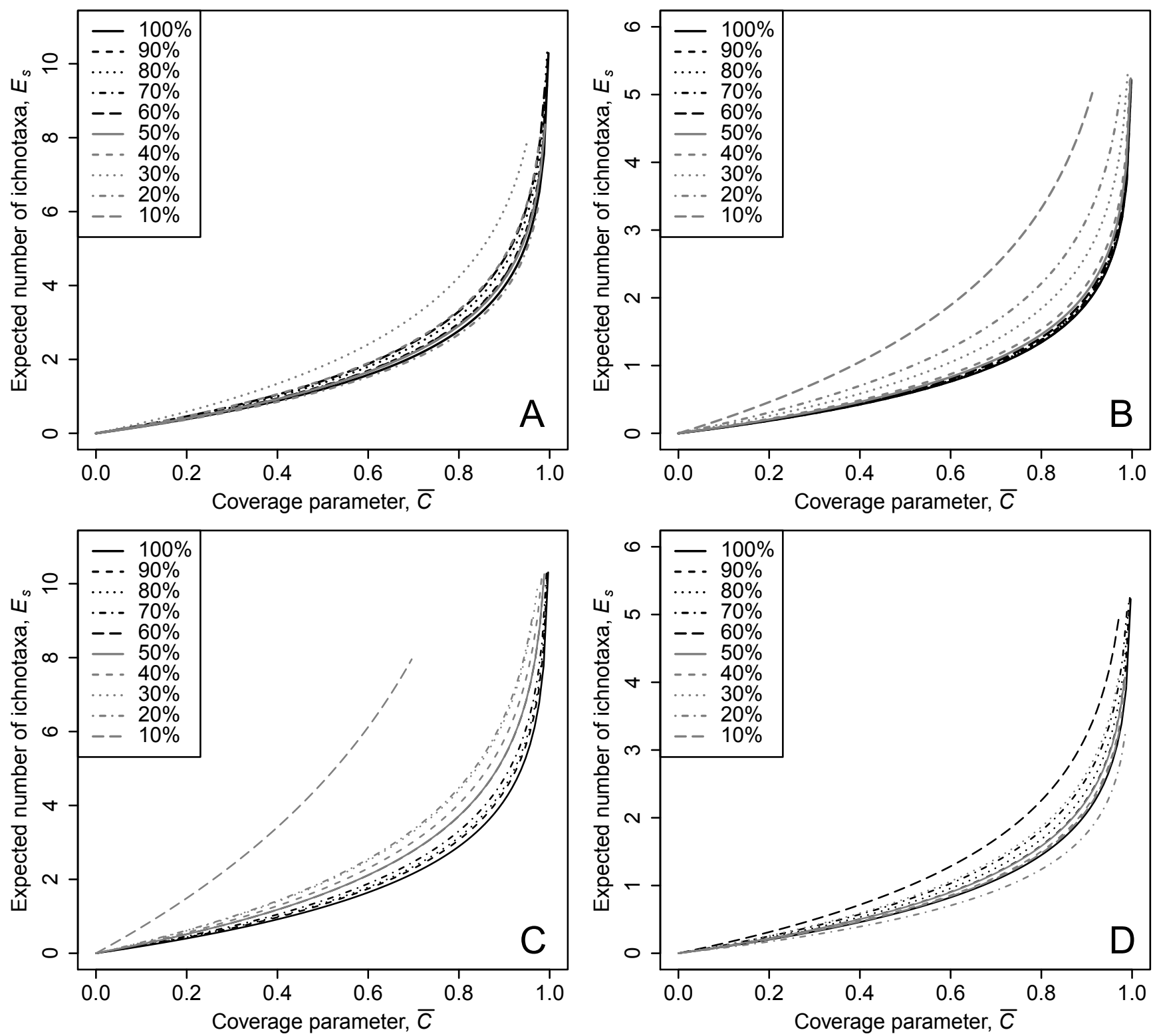

Fig. 6 

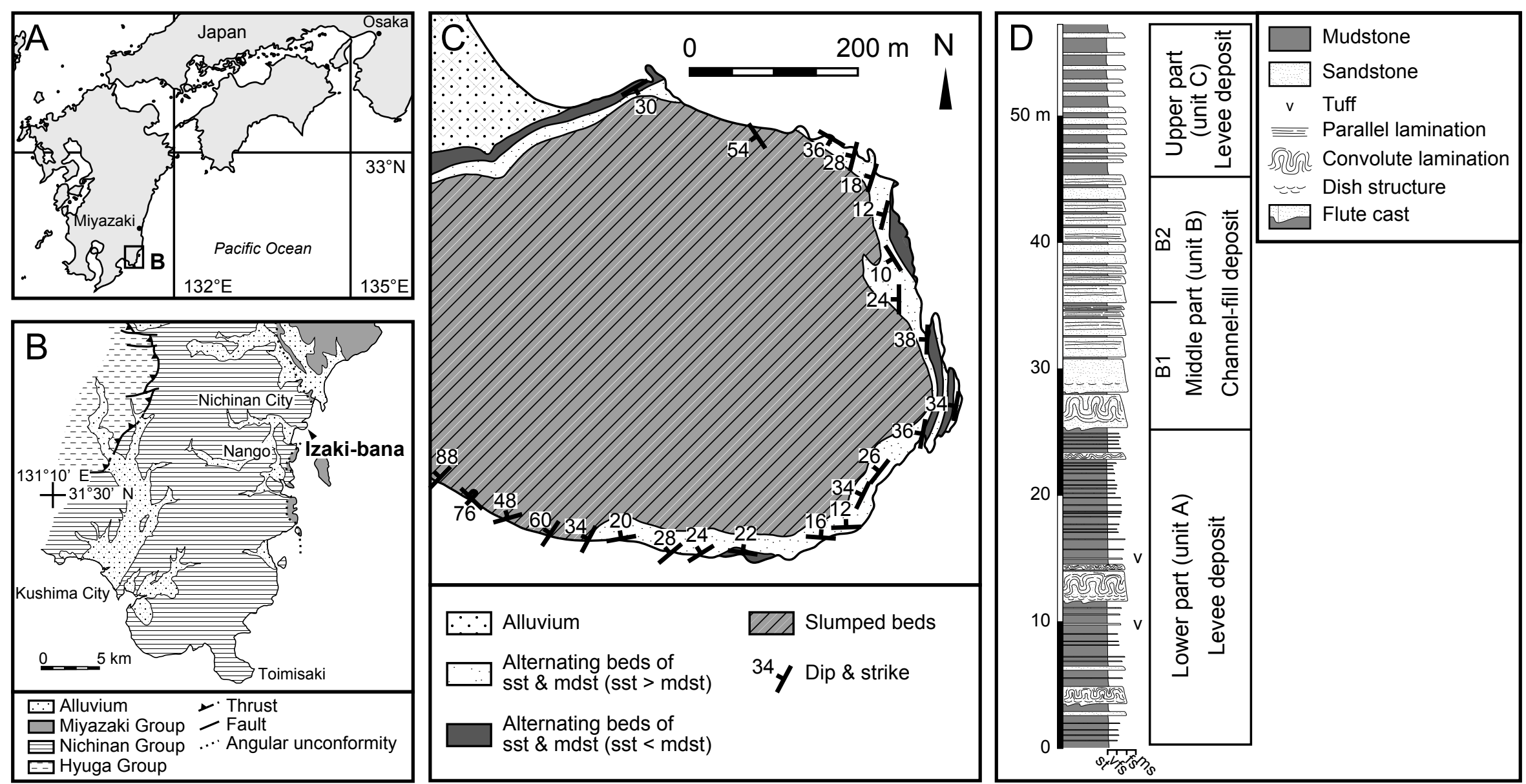

Fig. 7 

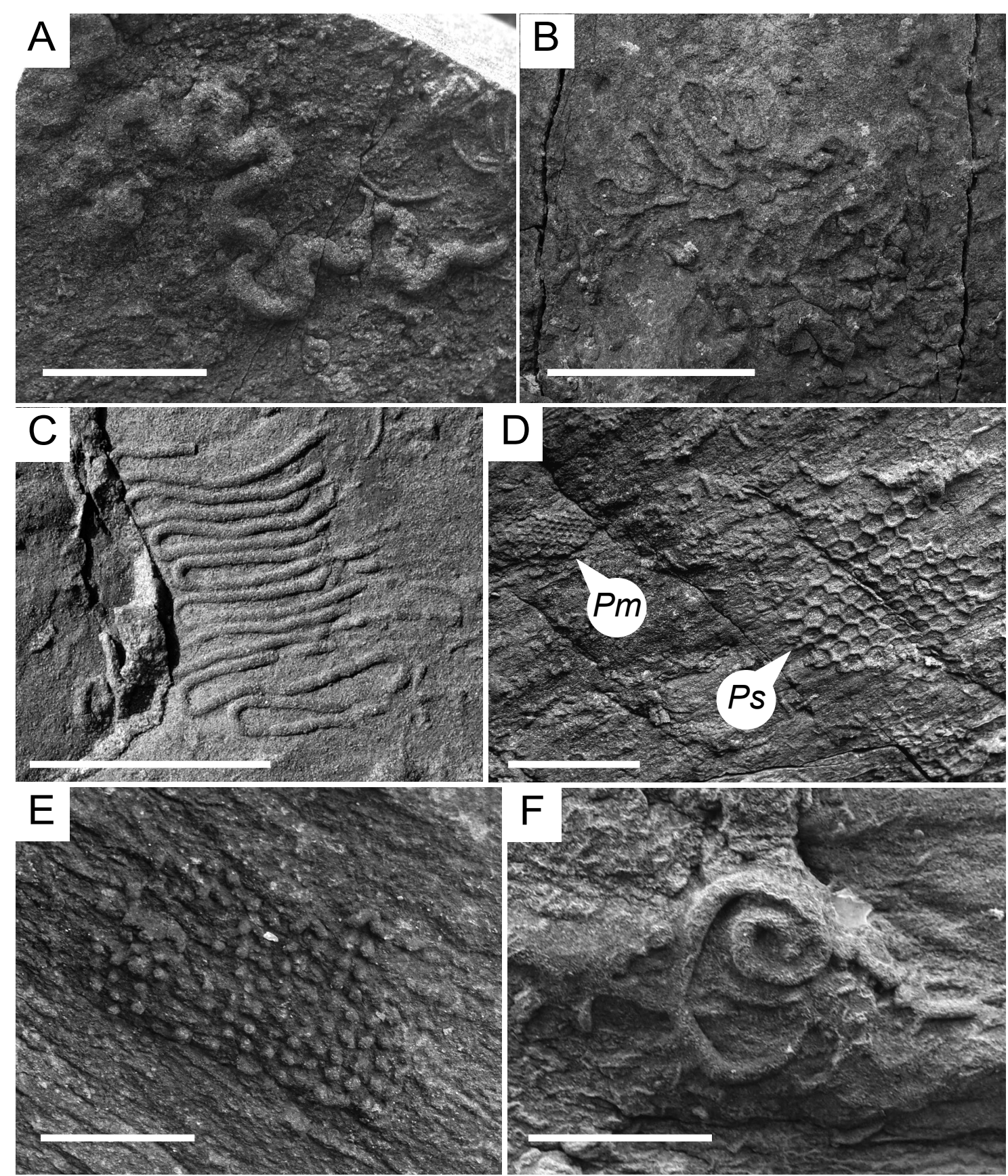

Fig. 8 

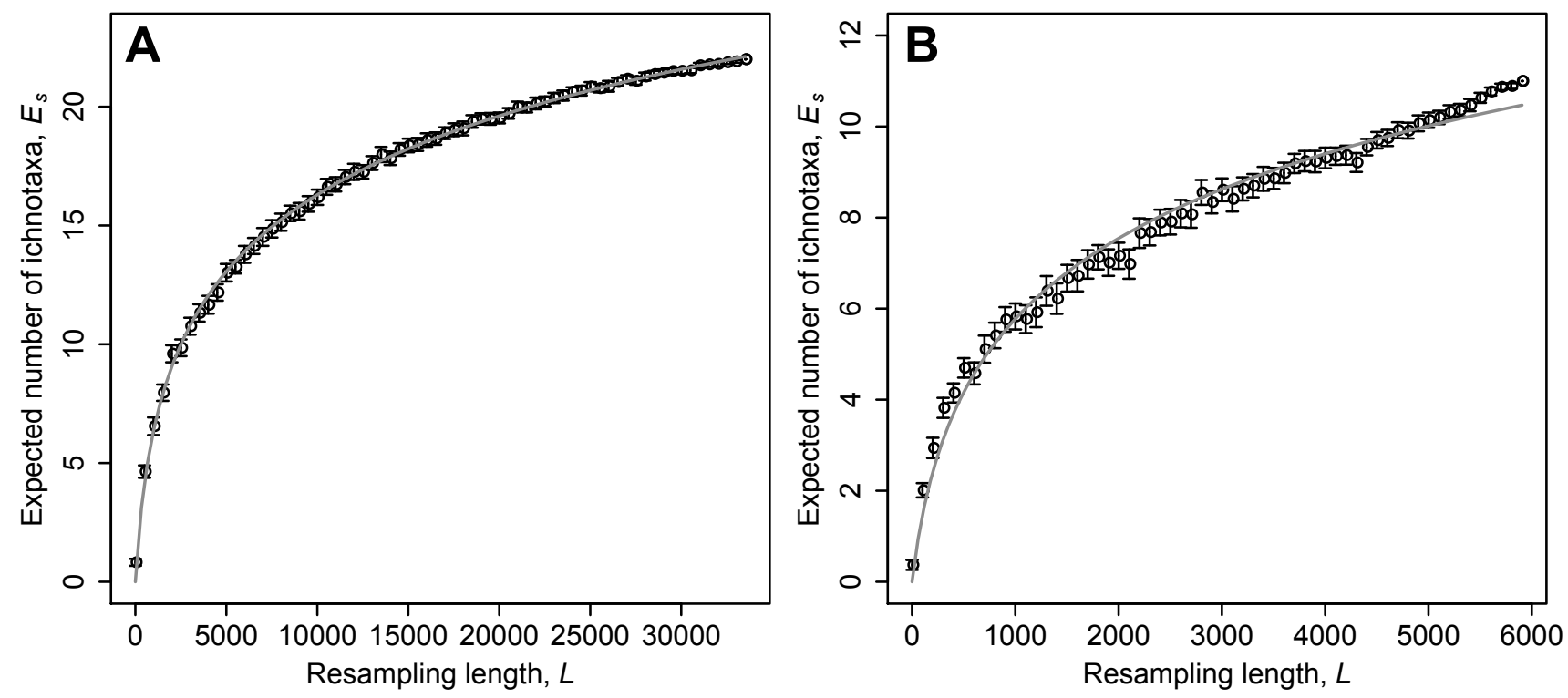

Fig. 9 


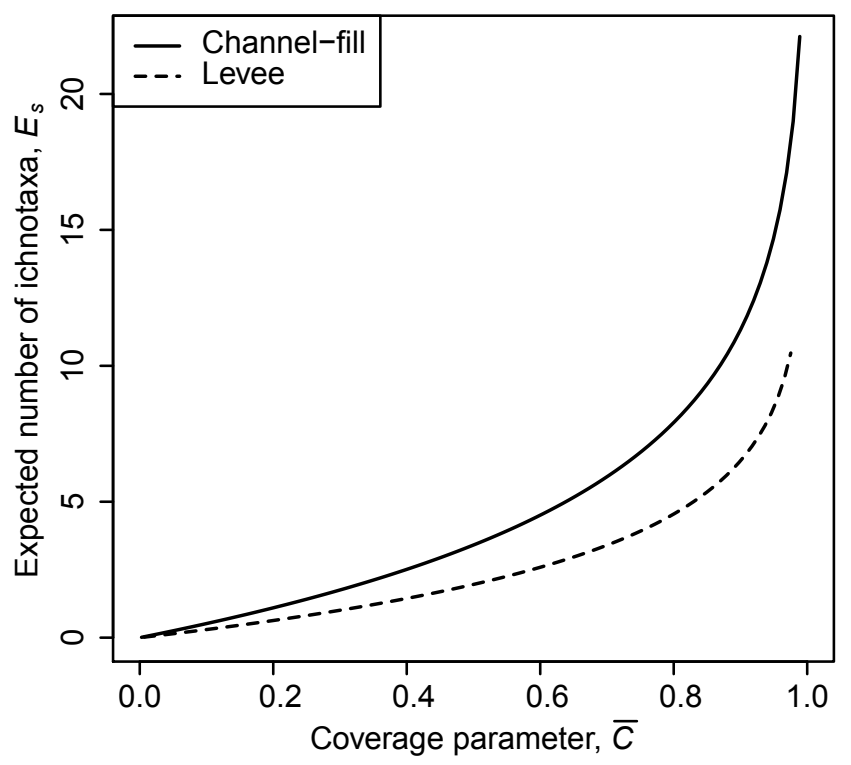

Fig. 10 


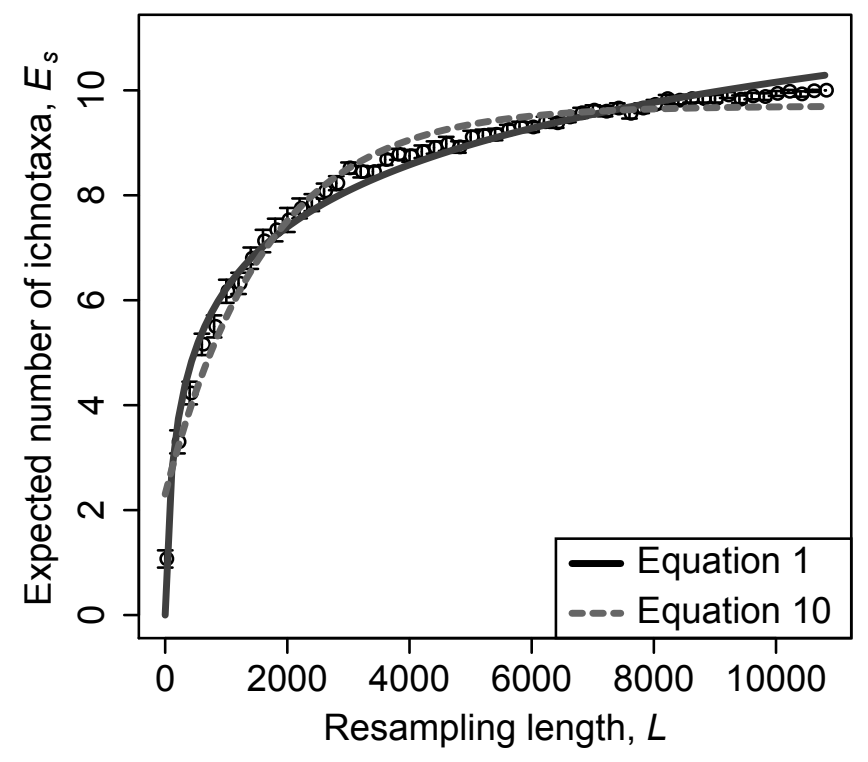

Fig. 11 


\begin{tabular}{|c|c|c|c|c|c|c|c|c|c|}
\hline \multirow{2}{*}{$\begin{array}{c}\text { Distribution } \\
\text { patterns } \\
\end{array}$} & \multirow{2}{*}{ Exposure } & \multicolumn{3}{|c|}{$a_{1}$} & \multicolumn{3}{|c|}{$a_{2}$} & \multirow{2}{*}{$R_{\mathrm{se}}$} & \multirow{2}{*}{ Ratio } \\
\hline & & Estimate & Std. Error & $\underline{p}$ & Estimate & Std. Error & $\underline{p}$ & & \\
\hline \multirow{10}{*}{$\begin{array}{c}\text { uniform w/ } \\
10 \text { ichnotaxa }\end{array}$} & $100 \%$ & 1.726 & 0.041 & $1.440 \mathrm{E}-42$ & 0.036 & 0.004 & $4.960 \mathrm{E}-11$ & 0.236 & - \\
\hline & $90 \%$ & 1.847 & 0.049 & $3.700 \mathrm{E}-22$ & 0.026 & 0.003 & 7.010E-08 & 0.178 & 1.070 \\
\hline & $80 \%$ & 1.966 & 0.065 & $5.890 \mathrm{E}-20$ & 0.022 & 0.003 & $9.820 \mathrm{E}-07$ & 0.230 & 1.139 \\
\hline & $70 \%$ & 1.837 & 0.073 & $2.730 \mathrm{E}-18$ & 0.022 & 0.004 & $8.690 \mathrm{E}-06$ & 0.252 & 1.065 \\
\hline & $60 \%$ & 2.051 & 0.068 & $5.490 \mathrm{E}-20$ & 0.015 & 0.002 & $1.010 \mathrm{E}-07$ & 0.216 & 1.188 \\
\hline & $50 \%$ & 1.812 & 0.061 & $6.910 \mathrm{E}-20$ & 0.018 & 0.002 & $1.330 \mathrm{E}-07$ & 0.194 & 1.050 \\
\hline & $40 \%$ & 2.073 & 0.029 & $2.060 \mathrm{E}-28$ & 0.011 & 0.001 & $1.480 \mathrm{E}-16$ & 0.078 & 1.201 \\
\hline & $30 \%$ & 2.628 & 0.107 & 4.990E-18 & 0.006 & 0.001 & $3.820 \mathrm{E}-09$ & 0.203 & 1.523 \\
\hline & $20 \%$ & 1.667 & 0.044 & $2.700 \mathrm{E}-22$ & 0.017 & 0.001 & $2.340 \mathrm{E}-11$ & 0.109 & 0.966 \\
\hline & $10 \%$ & 1.811 & 0.069 & $1.190 \mathrm{E}-18$ & 0.013 & 0.001 & $2.280 \mathrm{E}-10$ & 0.112 & 1.049 \\
\hline \multirow{10}{*}{$\begin{array}{l}\text { uniform w/ } \\
5 \text { ichnotaxa }\end{array}$} & $100 \%$ & 0.835 & 0.035 & $2.630 \mathrm{E}-30$ & 0.047 & 0.011 & $4.250 \mathrm{E}-05$ & 0.205 & - \\
\hline & $90 \%$ & 0.836 & 0.033 & $1.960 \mathrm{E}-18$ & 0.052 & 0.011 & $9.990 \mathrm{E}-05$ & 0.124 & 1.001 \\
\hline & $80 \%$ & 0.853 & 0.030 & $2.010 \mathrm{E}-19$ & 0.051 & 0.009 & $2.060 \mathrm{E}-05$ & 0.114 & 1.022 \\
\hline & $70 \%$ & 0.857 & 0.034 & $2.140 \mathrm{E}-18$ & 0.058 & 0.012 & 7.690E-05 & 0.127 & 1.027 \\
\hline & $60 \%$ & 0.878 & 0.037 & $9.380 \mathrm{E}-18$ & 0.059 & 0.013 & $1.290 \mathrm{E}-04$ & 0.138 & 1.052 \\
\hline & $50 \%$ & 0.907 & 0.041 & $4.950 \mathrm{E}-17$ & 0.060 & 0.014 & $2.085 \mathrm{E}-04$ & 0.151 & 1.086 \\
\hline & $40 \%$ & 0.954 & 0.048 & $6.080 \mathrm{E}-16$ & 0.058 & 0.014 & 4.191E-04 & 0.174 & 1.143 \\
\hline & $30 \%$ & 1.144 & 0.062 & $3.060 \mathrm{E}-15$ & 0.031 & 0.007 & $1.306 \mathrm{E}-04$ & 0.200 & 1.371 \\
\hline & $20 \%$ & 1.374 & 0.037 & $3.770 \mathrm{E}-22$ & 0.017 & 0.001 & $2.720 \mathrm{E}-11$ & 0.090 & 1.646 \\
\hline & $10 \%$ & 2.064 & 0.047 & $1.300 \mathrm{E}-23$ & 0.010 & 0.001 & $1.450 \mathrm{E}-15$ & 0.066 & 2.472 \\
\hline \multirow{10}{*}{$\begin{array}{c}\text { patchy w/ } \\
10 \text { ichnotaxa }\end{array}$} & $100 \%$ & 1.797 & 0.046 & $1.380 \mathrm{E}-40$ & 0.029 & 0.004 & $2.030 \mathrm{E}-10$ & 0.263 & - \\
\hline & $90 \%$ & 1.906 & 0.065 & $1.140 \mathrm{E}-19$ & 0.023 & 0.004 & $2.530 \mathrm{E}-06$ & 0.234 & 1.061 \\
\hline & $80 \%$ & 1.949 & 0.072 & $5.990 \mathrm{E}-19$ & 0.023 & 0.004 & $5.380 \mathrm{E}-06$ & 0.254 & 1.085 \\
\hline & $70 \%$ & 2.056 & 0.085 & $6.910 \mathrm{E}-18$ & 0.020 & 0.004 & $1.200 \mathrm{E}-05$ & 0.290 & 1.144 \\
\hline & $60 \%$ & 2.307 & 0.072 & $1.500 \mathrm{E}-20$ & 0.013 & 0.002 & $2.220 \mathrm{E}-08$ & 0.223 & 1.284 \\
\hline & $50 \%$ & 2.310 & 0.076 & 4.790E-20 & 0.016 & 0.002 & $5.390 \mathrm{E}-08$ & 0.235 & 1.286 \\
\hline & $40 \%$ & 2.510 & 0.069 & $6.690 \mathrm{E}-22$ & 0.014 & 0.001 & $4.060 \mathrm{E}-10$ & 0.195 & 1.397 \\
\hline & $30 \%$ & 2.735 & 0.050 & $7.580 \mathrm{E}-26$ & 0.011 & 0.001 & $1.200 \mathrm{E}-14$ & 0.124 & 1.523 \\
\hline & $20 \%$ & 2.783 & 0.083 & $5.660 \mathrm{E}-21$ & 0.012 & 0.001 & $4.970 \mathrm{E}-11$ & 0.181 & 1.549 \\
\hline & $10 \%$ & 6.682 & 0.255 & $1.300 \mathrm{E}-18$ & 0.002 & 0.000 & $1.830 \mathrm{E}-14$ & 0.101 & 3.719 \\
\hline \multirow{10}{*}{$\begin{array}{c}\text { patchy w/ } \\
5 \text { ichnotaxa }\end{array}$} & $100 \%$ & 0.900 & 0.030 & $2.890 \mathrm{E}-35$ & 0.031 & 0.005 & $1.360 \mathrm{E}-07$ & 0.169 & - \\
\hline & $90 \%$ & 0.989 & 0.043 & $1.900 \mathrm{E}-17$ & 0.021 & 0.004 & $4.340 \mathrm{E}-05$ & 0.151 & 1.098 \\
\hline & $80 \%$ & 1.046 & 0.048 & $8.100 \mathrm{E}-17$ & 0.017 & 0.003 & 4.730E-05 & 0.164 & 1.162 \\
\hline & $70 \%$ & 1.124 & 0.018 & $6.260 \mathrm{E}-27$ & 0.012 & 0.001 & $1.020 \mathrm{E}-13$ & 0.058 & 1.249 \\
\hline & $60 \%$ & 1.401 & 0.034 & $4.710 \mathrm{E}-23$ & 0.005 & 0.000 & $2.580 \mathrm{E}-12$ & 0.081 & 1.556 \\
\hline & $50 \%$ & 0.983 & 0.050 & $8.270 \mathrm{E}-16$ & 0.011 & 0.002 & $1.570 \mathrm{E}-05$ & 0.145 & 1.092 \\
\hline & $40 \%$ & 0.934 & 0.034 & 3.650E-19 & 0.018 & 0.002 & $1.690 \mathrm{E}-07$ & 0.102 & 1.038 \\
\hline & $30 \%$ & 1.159 & 0.065 & $5.900 \mathrm{E}-15$ & 0.010 & 0.002 & 7.610E-06 & 0.156 & 1.288 \\
\hline & $20 \%$ & 0.770 & 0.074 & $3.490 \mathrm{E}-10$ & 0.032 & 0.011 & $9.245 \mathrm{E}-03$ & 0.218 & 0.855 \\
\hline & $10 \%$ & 0.918 & 0.098 & $2.450 \mathrm{E}-09$ & 0.032 & 0.011 & $6.280 \mathrm{E}-03$ & 0.237 & 1.019 \\
\hline
\end{tabular}

Table 1 


\begin{tabular}{|c|c|c|c|c|}
\hline & $\begin{array}{c}\text { uniform w/ } \\
10 \text { ichnotaxa }\end{array}$ & $\begin{array}{l}\text { uniform w/ } \\
5 \text { ichnotaxa }\end{array}$ & $\begin{array}{c}\text { patchy w/ } \\
10 \text { ichnotaxa }\end{array}$ & $\begin{array}{c}\text { patchy w/ } \\
5 \text { ichnotaxa }\end{array}$ \\
\hline $\begin{array}{c}\text { uniform w/ } \\
10 \text { ichnotaxa }\end{array}$ & - & 0.484 & 1.041 & 0.522 \\
\hline $\begin{array}{l}\text { uniform w/ } \\
5 \text { ichnotaxa }\end{array}$ & 2.067 & - & 2.152 & 1.078 \\
\hline $\begin{array}{l}\text { patchy w/ } \\
10 \text { ichnotaxa }\end{array}$ & 0.961 & 0.465 & - & 0.501 \\
\hline $\begin{array}{l}\text { patchy w/ } \\
5 \text { ichnotaxa }\end{array}$ & 1.917 & 0.927 & 1.996 & - \\
\hline
\end{tabular}

Table 2 


\begin{tabular}{|c|c|}
\hline $\begin{array}{l}\text { Sedimentary } \\
\text { environments }\end{array}$ & Ichnotaxa \\
\hline $\begin{array}{l}\text { Levee } \\
\text { (11 ichnogenera } \\
12 \text { ichnospecies) }\end{array}$ & $\begin{array}{l}\text { Bergaueria isp. } \\
\text { Gordia marina } \\
\text { Gordia isp. } \\
\text { Helminthpsis abeli } \\
\text { Megagrapton irregulare } \\
\text { Nereites missouriensis } \\
\text { Paleodictyon strozzii } \\
\text { Paleophycus isp. } \\
\text { Phycosiphon incertum } \\
\text { Spirorhaphe involuta } \\
\text { Circular trace } \\
\text { Radial trace }\end{array}$ \\
\hline $\begin{array}{l}\text { Channel-fill } \\
\text { ( } 22 \text { ichnogenera } \\
24 \text { ichnospecies) }\end{array}$ & $\begin{array}{l}\text { Asteriacites lumbricalis } \\
\text { Belorhaphe zickzack } \\
\text { Bergaueria isp. } \\
\text { Cosmorhaphe parva } \\
\text { Desmograpton ichtyforme } \\
\text { Gordia marina } \\
\text { Gordia isp. } \\
\text { Halopoa imbriata } \\
\text { Helminthopsis abeli } \\
\text { Helminthorhaphe japonica } \\
\text { Lorenzinia isp. } \\
\text { Mammillichnis aggeris } \\
\text { Megagrapton irregulare } \\
\text { Nereites missouriensis } \\
\text { Paleodictyon minimum } \\
\text { Paleodictyon strozzii } \\
\text { Paleophycus isp. } \\
\text { Phycosiphon incertum } \\
\text { Punctorhaphe parallela } \\
\text { Spirophycus bicornis } \\
\text { Spirorhaphe involuta } \\
\text { Bloom like trace } \\
\text { Circular trace } \\
\text { Radial trace }\end{array}$ \\
\hline
\end{tabular}

\section{Table 3}




\begin{tabular}{|c|c|c|c|c|c|c|c|}
\hline & \multicolumn{3}{|c|}{$a_{1}$} & \multicolumn{3}{|c|}{$a_{2}$} & \multirow{2}{*}{$R_{s e}$} \\
\hline & Estimate & Std. Error & $p$ & Estimate & Std. Error & $p$ & \\
\hline Channel-fill & 4.916 & 0.035 & $6.994 \mathrm{E}-85$ & 2.650.E-03 & 7.171.E-05 & $2.733 \mathrm{E}-46$ & 0.180 \\
\hline Levee & 2.825 & 0.077 & $2.050 \mathrm{E}-42$ & 6.722.E-03 & 5.841.E-04 & $1.030 \mathrm{E}-16$ & 0.300 \\
\hline
\end{tabular}

Table 4 